\title{
Introduction
}

\section{Innovative approaches to teaching and learning in library and information science}

Over the past two decades, the higher education (HE) has been the focus of many professionals and educational bodies. This is true for Library and Information Science (LIS) education which has been in particular sensitive to changes resulting in various attempts to modernize educational programs and didactics. In order to address these challenges and the disruptive forces in today's environment, LIS shools and departments need to re-examine the existing teaching/learning models. Problems related to teaching and learning are closely connected with the nature of education which has been addressed recently by pedagogues and HE policy makers (Virkus, 2008, 2015; European Commission, 2011, 2013; Borrego, 2015; Sursock, 2015; Luna Scott, 2015), as well as the identity of the field, levels and structures of programmes offered, learning outcomes and their impact on students' general success. However, less attention has been paid to didactic approaches and to innovative teaching methods. There are however examples of attempts to bring in new teaching methods and to focus more on student learning needs and preferences. What this means and how these innovative approaches and models affect the learning goals and outcomes are questions which have not been yet tackled fully. With this special issue on "Innovative Approaches to Teaching and Learning in LIS", we hope to contribute to the wide literature on education of future information professionals by paying special attention to new trends, new models, critiques of the innovative approaches and didactic experiences from the point of view of students and faculty in the LIS field.

It is well known that education in general, and distance education including online education systems in particular, inherited theories and models from Didactics as a special field of Pedagogy. ${ }^{1}$ Didactics deals with theories, ideas, principles, and instructional design and applications that support a successful realization of educational process. Didactics in the $21^{\text {st }}$ century is a rather challenging area whether it aims at discovering new models and methods appropriate for the current generation of learners as well as teachers which are confronted on one hand with technical and economic developments, and on the other hand, with the need for constant adaptation to diverse cultural and uncertain socio-political and ecological environments.

Methods, theories and principles in education have been evolving for centuries. The first evidence of systematic teaching began over a thousand years ago in old

\footnotetext{
${ }^{1}$ Some parts of this Introduction are based upon the chapter in the Didactic Framework document produced for the EINFOSE project. Cf. Aparac-Jelušić (2018). An Overview of Didactic Approaches in the $21^{\text {st }}$ Century, 2018.
} 
Sumerian, Egyptian and ancient Greek civilizations. However, it was conducted for the chosen few literate persons only. It was only at the beginning of the 17th century that mass education of youth began and the first educational curricula were developed.

Socrates introduced a dialogic method which is popular even today, especially in the educational area that uses the so-called critical thinking. Other approaches started to be in practice from the beginnings of modern pedagogy and the related work of a Czech pedagogue Jan Komenski, and several other reformists such as J. F. Herbart, G. Kerschensteiner, H. Parkhurst, J. Dewey, W. H. Kilpatrick, who have offered the basic theoretical frameworks for didactics and pedagogy in general.

The development of didactic theory and practice was intensified towards the end of 20th century and many application of proposed didactics frameworks were described and evaluated. Broad concepts of constructivism and socio-cultural learning theories seem to have replaced education theory and didactics as conceptual framework which aimed at reasoning about the teaching goals and practice in HE. According to Qvortrup et al. (2016, p. 163), Luhmann's interpretation of didactics as theories or programs for reflection is highly inspiring to start looking at different theories and approaches that have been discussed in relation to the growing need to understand societal change.

As didactics has been using theoretical models developed in philosophy, psychology and sociology in order to design theoretical models of teaching and learning, it is confronted with concepts offered by theoreticians who have often been in disagreement, depending on their starting positions. It is widely accepted that early didactic concepts, for instance, were directed towards teaching and the teacher's role in education, while newer concepts focus more on the student and his/her place in the learning process. As expected, attention has been paid also to didactics of e-education which draws on application possibilities of Information and Communication Technologies (ICTs) and acceptable models of instructional design (ID) which actually had roots in programmed learning and computer based instruction. It is interesting to note that authors who deal with electronic learning (e-learning) often see this as a recent initiative and are not aware of the fact that e-learning started as early as in 1950s. At that time, a wide base of didactics already existed and it should have been approached with critical appraisal models that were introduced in order to satisfy an ever growing educational needs of new generations. The role of instructional design in e-learning has been often misunderstood due to the perceived complexity of the process and to poor understanding of the pedagogical requirements of e-learning (Siemens, 2002).

The dominant philosophies of learning and teaching have undergone significant changes and developmental paths over the past century - from behaviourism, to Gestalt and Denkpsychology and from the mid 20th century cognitive psychology. During the 1970s and 1980s, another theory emerged to overcome the limits of cognitive approaches - constructivism - which suggested a more student-centred approach to instruction and the new role of the teacher who was not seen only as the 
direct transmitter of knowledge, but rather as a facilitator of an active, self-directed construction of knowledge (Brown et al., 1989, p. 32). Numerous instructional approaches were and still are based on constructivism. At the end of the 20th century, the ideas of Vygotsky and culturally comparative research (Vieluf et al., 2012, pp. 28-29) influenced the so called socio-constructivist theories. The focus here is on examining the interaction of psychological processes within the learner with social and situational characteristics of the learning process. These theories introduced the notions of 'self-directed learning', 'co-operative learning', 'self-regulated learning', 'guided discovery', 'scaffolding', 'cognitive apprenticeship', 'teacher-mediated dialogue', 'independent group discussion', 'problem-based learning', 'project-based learning', 'knowledge building' etc. (Vieluf et al., 2012).

In the United States, as discussed by Marchionini and Moran (2012), much attention in the higher education area "has been spawned by utilitarian concerns about economic costs and subsequent career return on investment, and by innovations in technology that lead to globalization and alternative models of teaching and learning" (ibid: p. III). In Europe, as well as in other developed parts of the Globe, we can see similar concerns, but the new models embracing ICT and new didactics are not yet applied everywhere at the same level and with the same reliance.

At the policy making and funding level, since the 1990s, several action programs have had a significant impact on collaboration between Higher Education Institutions (HEIs) in Europe, including attempts to foster mobility of teachers and students and modernize education by the use of ICT and research (for instance, Tempus, Leonardo da Vinci, and Erasmus programs). These attempts were funded under projects known as eEurope 2002, eLearning Programme 2004-2006, Europe 2020 Strategy. Innovation in education and training became a key priority in several flagship initiatives of the Europe 2020 Strategy, such as Agenda for New Skills and Jobs, Youth on the Move, Digital Agenda (European Commission 2011, 2013), where the contribution of ICT for achieving these targets was recognized (Aparac-Jelušić, 2017), and financial support given to investigate new models and frameworks for education at HEIs. However, after a period of 15 years of major reforms across Europe as part of the Bologna Process, it is evident that the implementation of all anticipated reforms is far from being realized in all countries and with the same level of conviction about the need to accept all of the recommendations.

Recent discussions have been touching questions such as: What happens when previous assumptions (based upon various models already mentioned above) about education no longer apply, and did they change at all?

There is no doubt that in the 21st century the Internet has created a wide online learning environment, giving rise to new situations with the abundancy of information, growing numbers of teachers and global learning challenges. The traditional methods of instructing students - such as memorization, repetition, and basic comprehension - are no longer sufficient. The new environment allows both - students and teachers - to select the content they prefer, and to decide the time and place for 
teaching/learning which take actions in personalized, mobile, student-driven environment that penetrate the arena from the end of the $20^{\text {th }}$ century and current system education (Mancabelli, 2012). However, the new opportunities are not embraced with the same intensity in all parts of the Globe, mostly because of the unequal availability of technology and human resources. According to Kapitzke (2006) 21st century school-aged students are rapid processors of information and demand more expedient methods of instruction and communication, especially when enrolled at HEIs. In order to better understand the 21st century educational context, Owston (2007), Scardamalia and Bereiter (2006) suggested that it may be helpful to start from the fact that mere declarative knowledge has given way to knowledge building processes which pay attention to students who are not only being asked to know about the subject at hand, but also to apply the information in novel situations, think critically about the material, apply the information, and evaluate its appropriateness.

For some authors, there is a need for new didactics (for example, Greenlaw, 2015), some are proposing their own approach in dealing with challenges (cf. Mancabelli, 2012; Open University, 2017). It could be expected that educational arena at all levels - confronted with an awareness that current theories and models are crumbling - should look at new didactics as a base for overcoming the unwanted and often unpredictable implications of a global network of people and information on education in general, and curriculum, instruction and assessment in particular.

Three components of the didactics framework are present in various approaches to modern education. Namely, each didactics framework consists of a) a set of human beings with relations (e.g. students and teachers in a classroom or on a certain learning platform); b) an organisation of human practice and knowledge, and c) a set of artefacts used to mediate and relate the previous two (Winslow, 2010). By analysing their similarities and differences, the rational justifications - when selecting an appropriate and useful theoretical framework with respect to a given purpose - could be facilitated.

There is a number of successful models of teaching and learning that new didactics could emulate and build on (Brown, 2006). However, new approaches are mostly focused on how to exploit ICT and Internet in order to offer some innovative approaches and to achieve optimal results in teaching/learning processes, for example in Open and Distance Learning (ODL) and design of Virtual Learning Environments (VLEs); on-line study programs and courses; virtual universities, etc. (Ravenscroft, 2001, p. 133). Online learning opportunities result in new players and forms of learning (e.g., MOOCs and globalising university services) and new forms of recognition for skills acquisition (e.g., Open Badges). It is also worth noting that 21st-century learning skills and competencies seen from the perspective of employers are mainly based on philosophies of communication, collaboration and creativity, as well as on their need to employ workers who will be able to tackle and deal with ever growing challenges in modern economy.

Up to now research has been verifying the value of information and communication technology in the education systems worldwide. It has demonstrated that ICT can: 
- reduce learning barriers (e.g. Rose et al., 2002),

- improve academic success (e.g. Wenglinsky, 2005),

- increase students' chances for learning success (e.g. Slavin, 2005),

- create a greater sense of adaptive communication and school community (e.g. Zhang et al., 2007), and

- provide greater opportunity for flexible access to learning (e.g. Palloff \& Pratt, 1999).

However, new approaches aimed at educational reform called for a paradigm shift from instructor to learner-centred domain knowledge learning. In line with such efforts, Marshall et al. (2010) suggested that the inquiry-based learning pedagogy could well support learner-centred learning by helping learners to develop inquiry skills which are an important part of 21st century skills and competencies, perhaps, the most influential approach that has come under a lot of criticism recently. The education literature features a number of discussions about 21 st century skills and learning (Scardamalia \& Bereiter, 2006; Brown, 2006; Walser, 2008; Wagner, 2008; Johnson, 2009; Saavedra \& Opfer, 2012).

Regardless of the skills included or the terms used to describe them, all 21stcentury skills definitions are relevant to many aspects of life in today's complex world. Most of these skills focus on similar types of complex thinking, learning, and communication skills. These skills are also commonly referred to as higher-order thinking skills, deeper learning outcomes, and complex thinking and communication skills (Saavedra \& Opfer, 2012, p. 8). To ease the way for these skills to be introduced into didactics frameworks, Saavedra and Opfer (2012, p. 11) suggested nine 'rules' which basically frame their didactics model:

- teachers should think of how to make their teaching innovative and relevant;

- at the same time teachers should foster permeating across the disciplines;

- they should foster development of thinking skills;

- teachers should encourage learning transfer;

- they should teach students how to learn,

- and teach students how to work in teams;

- teachers should foster creativity;

- teachers should also constantly exploit technology to support learning;

- they should address misunderstandings directly to allow students to express their dissatisfaction in cases where they feel uncomfortable with the teacher's approach or communication with them or with fellow students.

Another approach known as transformative pedagogy has in its focus to encourage teachers to do much more than transmitting information. Moreover, the transformative pedagogy seeks to "fundamentally and respectfully change students' attitudes and analytic skills to facilitate their growth, regardless of whether the course is delivered through a traditional or online format" (Meyers, 2008, p. 220). Basically, transformative pedagogy aims to critically examine students' assumptions, to explain how they cope with social issues, and engage in social action. 
One area that has been addressed in many approaches to modern didactics is the issues of innovative methods and creativity - relating to both teacher's and student's creativity. As Prensky (2010) claimed, today's students have vastly different interests, skills, and brain functions that are not always recognized or attended to within many contemporary school systems. However, focusing pedagogical designs only on innovation and creativity supported by ICT is obviously not sufficient to improve teaching/learning practice. Purely technophilic approaches threaten to allow the educational arena to be overwhelmed by ICT and to neglect the role of teacher and of human values (Postman, 1993; Greenlaw, 2015). Prensky (2010) and his 'technophilic followers' intend to provide educators with effective ways to involve their students in experiential learning partnerships through the use of serious games, e-books, crowdsourcing, and Facebook. Already a quarter of century ago, Postman (1993) expressed doubts in relation to the taken-for-granted assumptions about the role of technology in education and warned about the influence of totalitarian technocracy on moral development and cultural identity formation when collective intelligence, hypertexts, and virtual relationships displace traditional textbook and face-to-face modes of learning. Instead of placing too much emphasis upon ICT and the power of information, new approaches should value the attainment of wisdom in education and focus on the role of the teacher as an experienced expert who can frame students' learning. As Greenlaw (2015, p. 897) wisely notes "teaching is not simply a matter of turning on a computer or an iPad and setting students loose to solve a problem or to do a project".

If we focus on the current prevailing opinion and understanding that the knowledge that formed the basis of progress in the 19th and 20th centuries is insufficient in the 21 st century, it is necessary to face challenges and find possible solutions for future developments in the society as a whole, and in the education field in particular. The Industry 4.0 or co-called fourth industrial revolution which advocates automation and data exchange in manufacturing technologies, including cyber-physical systems, the Internet of things, cloud computing and cognitive computing (Botha \& Theron, 2016), is approaching fast and brings in new principles that primarily support the economy and determine the scenarios of their implementation. As one looks at these principles (interoperability, informational transparency, technical support, decentralised decision-making) and their application in a future working environment which will need professionals with competency-based knowledge, communication competence 4.0 (which refers to professional skills e.g. basic and specialist knowledge from a person's own specialty/discipline, data and IT skills to social competence and personal skills), ability to develop systems and ability to work with decentralized decision-making systems (Flogie et al., 2018, pp. 267-268), it becomes clear that the reform of teacher education programs is needed in order to provide them with a more comprehensive understanding of how cognition, motivation, teaching and learning relates to each other. Moreover, teachers should be able to overcome the bias between technology related goals and humanistic approaches which could enrich the skills and competencies needed and be able to guide learners in a way to 
soften the technophilic approach and bring into modern education, a humanistic dimension. In line with such a need, it could be pointed out that LIS education needs to recognise the valuable support of librarians and other information specialists in educational processes, from elementary school teaching to secondary and tertiary level and life long education.

In the latest report about innovative pedagogy published in 2017 (Open University, 2017, p. 3), authors discussed innovations that have the potential to provoke major shifts in educational practice. Each trend is rated based on its impact (high or medium) and placed on a timeline for adoption (ongoing, 2-5 years, 4+ years): Immersive Learning, Open Textbooks, Spaced Learning, Learning with Internal Values, Big-data Inquiry: Thinking with Data, Intergoup Empathy, Learners Making Science, Navigating Post-thruth Societies, Student-led Analytics, Humanistic Knowledge-building communities.

In recent years, several authors critically evaluated didactic models in use. According to Goldman et al. (1999), technology can facilitate deep exploration and the integration of information, high-level thinking, and profound engagement by allowing students to design, explore, experiment, access information, and model complex phenomena. They claimed that these new circumstances and opportunities - not the technology on its own - can have a direct and meaningful impact on student achievement. The technology learning versus content learning dilemma necessitates a call for more complex models and experiences for professional teacher development and more materials that support standards-based learning.

This calls for a new framework for didactics that could support or even predict educational needs in a near future. In $21^{\text {st }}$ century, the design of innovative teaching practices has been fostered by a vision that creative tasks of students should be implemented in every day teaching methodology and based on approved didactics which still lack the data resulting from research projects or scientific analysis of the complex educational arena.

Some authors investigated specific areas of their interest, such as Ghislandi and Facci (2013) who were interested in teachers' training role in the innovative use of the Interactive Whiteboard; Guo and Wouflin (2016) surveyed how the 21st-century learning framework reflects principles of creativity. Their study was based on a qualitative analysis of the Partnership for $21^{\text {st }}$ Century's (P21) policy documents with a specific focus on how the principles of creativity, one of the 4Cs (creativity, critical thinking, collaboration, and communication) of the P21 learning framework, are reflected in these documents. Cobo (2013) explored and discussed key conditions needed to develop skills for innovation by analysing five trends that can contribute to fostering the development of skills for innovation within and outside formal educational institutions. Flogie et al. (2018) addressed the intense introduction of ICT that align with educational trends and the requirements of today's society, but which sometimes neglects social competences and any potential psychosocial effects. A need for new and effective methods in upbringing and education to offer everyone 
equal opportunities become more and more important in the "world of the 21st century". Previous studies also showed that innovative didactics methods of teaching, using a transdisciplinary model supported by state-of-the-art information and communications technology as well as cooperative learning, have a positive psychosocial effect on science, technology, engineering and mathematics (STEM) students.

Finally, in this introductory overview of new didactic themas and dilemmas and how to approach innovative teaching and learning, it should be mentioned that numerous books dedicated to the new pedagogy and didactics have significantly influenced learning and teaching. However, there are not enough data dealing on the assessment of the new approaches and methods of teaching and learning in the digital environment. New educational principles which stem from the idea to use of technology in order to develop information and communication literacy, various approaches to the issue of creativity and innovation, new skills needed for competitive working environment, need to be verified through research based investigations which will include teachers and students (learners) and their feedback on new approaches and implemented models.

In Library and Information Science (LIS) education, there is still an increasing focus on information technologies (an inevitable result of massive technological advances). Further on, users perspectives, basic human values and the role of public funded information institutions in allowing free access to information, supporting freedom of expression and multi-disciplinarity, occupy an important place in LIS education as it seeks new and innovative ways of bringing to students' attention various topics and skills needed for their future jobs. There are new career opportunities for LIS graduates as new positions are opening up in areas such as knowledge management, information architecture, research data management, management of information services and human resources in a digital environment and digital humanities (Kurbanoglu, 2018).

While LIS education is transforming, the debate over education is intensifiying. Strategic decisions such as the changes in the structure, scope and focus of individual LIS schools and programs require not only a careful examination of the literature regarding the flux in the discipline, but also a careful examination of innovative pedagogies and new didactic trends (Kurbanoglu, 2018).

A progressive change from teacher-centered pedagogies and practices towards student-centered and more personalized learning has also been witnessed in LIS education. This means that students' needs, interests, backgrounds and learning styles are placed at the center and students start to become more actively and flexibly involved in the learning process. Advances in the areas of online educational programs and video content creation and delivery, have enabled the implementation of flexible and personalized learning spaces. Pedagogical approaches have become geared towards millennials' learning preferences, and have started to combine the traditional face-to-face classroom instruction with activities facilitated through a range of technological resources outside of the class. As a result, blended learning, flipped classroom model, online instruction, video based instruction and MOOC have emerged and become increasingly popular in LIS education (Kurbanoglu, 2018). 
With this special issue we hope to contribute to the body of literature on education of future information professionals by paying special attention to new didactic trends including gamification and flipped classroom, the impact of developments regarding MOOC, innovative approaches such as informal peer-learning, inter-organizational collaboration, the use of open badges and the development of professionally-oriented capstone modules.

\section{References}

Aparac-Jelušić, T. (2017). Digital libraries for cultural heritage: Development, outcomes, and challenges from European perspectives. Morgan \& Claypool.

Aparac-Jelušić, T. (2018). An Overview of Didactic Approaches in the 21st Century. In: Didactic Framework: EINFOSE Intellectual Output 4. Retrieved from: http://einfose.ffos.hr/documents.

Borrego, Á. (2015). Library and Information Education in Europe: an overview. BiD: textos universitaris de biblioteconomia i documentació, 35, http://bid.ub.edu/pdf/35/en/borrego.pdf.

Botha, T. \& Theron, P. (2016). How are companies around the world really embracing digital? Retrieved from: https://www.weforum.org/agenda/2016/05/industry-4-0.

Brown, J. S. (2006). New learning environments for the 21st century: Exploring the edge, The Magazine of Higher Learning, September/October, 18-24.

Brown, J. S., Collins, A. \& Duguid, P. (1989). Situated cognition and the culture of learning. Educational Researcher, 18(1), 32-42.

Cobo, C. (2013). Skills for innovation: envisioning an education that prepares for the changing world. The Curriculum Journal, 24(1), 67-85.

European Commission. (2011). An Agenda for the Modernisation of Europe's Higher Education Systems. Brussels, 20.9.2011 retrieved from: http://ec.europa.eu/education/library/policy/modernisation en.pdf.

European Commission. (2013). Opening up Education: Innovative teaching and learning for all through new Technologies and Open Educational Resources. Brussels, 25.9.2013. retrieved from: http://ec. europa.eu/transparency/regdoc/rep/1/2013/EN/1-2013-654-EN-F1-1.Pdf.

Flogie, A., Lakota, A. B., \& Aberšek, B. (2018). The Psychosocial and cognitive influence of ICT on competences of STEM students. Journal of Baltic Science Education, 17(2), 267-276. Retrieved from: http://www.p21.org/our-work/p21-framework.

Goldman, S., Cole, K. \& Syer, C. (1999). The technology: Content dilemma. The Secretary's Conference on Educational Technology. Retrieved from: https://www2.ed.gov/rschstat/eval/tech/techconf99/ whitepapers/paper4.html.

Greenlaw, J. (2015). Deconstructing the metanarrative of the 21 st century skills movement. Educational Philosophy and Theory, 47(9), 894-903. Retrieved from: http://dx.doi.org/10.1080/00131857. 2015.1035156.

Ghislandi, P. \& Facci, M. (2013). Schools in the Digital Age: Teachers' training role in the innovative use of the Interactive Whiteboard. Ricerche di Pedagogia e Didattica, 8(1), 1-18.

Guo, J. \& Woulfin, S. (2016). Twenty-first century creativity: An investigation of how the partnership for 21st century instructional framework reflects the principles of creativity. Roeper Review, 38, 153-161.

Johnson, P. (2009). The 21st century skills movement. ASCD Express, 67(1), 11. Retrieved from: http://www.ascd.org/publications/educational-leadership/sept09/vol67/num01/The-21st-CenturySkills-Movement.aspx.

Kapitzke, C. (2006). Internet chatrooms: E-space for youth of the risk society. In L. T. W. Hin, \& R. Subramaniam (Eds.), Handbook of Research on Literacy in Technology at the K-12 Level (pp. 158175). London: Idea Group Reference.

Kurbanoglu, S. (2018). Introduction. In: Didactic Framework: EINFOSE Intellectual Output 4. Retrieved from: http://einfose.ffos.hr/documents. 
Luna Scott, S. (2015). The Futures of learning 3: What kind of pedagogies for the 21st Centrury. Paris Unesco. Retrieved from: https://unesdoc.unesco.org/ark:/48223/pf0000243126.

Mancabelli, R. (2012). The three new pillars of 21st century learning. Retrieved from: www.District Administration.com.

Marchionini, G. \& Moran, B. (eds) (2012). Information Professionals 2050: Educational Possibilities and Pathways. North Carolina: School of Information and Library Science of University of North Carolina at Chapel Hill. Retrieved from: http://sils.unc.edu/sites/default/files/news/Information-Professionals2050.pdf.

Marshall, J. C., Smart, J. \& Horton, R. M. (2010). The Design and validation of EQUIP: An instrument to assess inquiry-based instruction. International Journal of Science and Mathematics Education, 8(2), 299-321.

Meyers, A. S. (2008). Using transformative pedagogy when teaching online. Journal of College Teaching, 56(4), 219-224.

Open University. (2017). Innovating Pedagogy. (Innovation Report 6). Retrieved from: www.open.ac.uk/ innovating.

Owston, R. (2007). Contextual factors that sustain innovative pedagogical practice using technology: an international study. Journal of Educational Change, 8(1), 61-77.

Palloff, R. M. \& Pratt, K. (1999). Building learning communities in cyberspace: Effective strategies for the online classroom. San Francisco, CA: Jossey-Bass.

Postman, N. (1993). Technopoly: The surrender of culture to technology. New York, NY: Random House.

Prensky, M. (2010). Teaching digital natives: Partnering for real learning. Thousand Oaks, CA: Corwin.

Qvortrup, A, Wiberg, M, Christensen, G. \& Hausbøl, M. (2016). On the definition of learning. Odense: University Press of Southern Denmark.

Ravenscroft, A. (2001). Designing e-learning interactions in the $21^{\text {st }}$ century: Revisiting and rethinking the role of theory. European Journal of Education, 36(2), 133-156.

Rose, D. H., Meyer, A, Strangman, N. \& Rappolt, G. (2002). Teaching every student in the digital age: Universal Design for learning. Association for Supervision and Curriculum Development (ASCD).

Saavedra, A. R. \& Opfer, V. D. (2012). Learning 21st-century skills requires 21 st-century teaching. Phi Delta Kappan, 94(2), 8-13. Retrieved from: https://www.researchgate.net/publication/262091816_ Learning_21st-Century_Skills_Requires_21st-Century_Teaching.

Scardamalia, M. \& Bereiter, C. (2006). Knowledge building: Theory, pedagogy, and technology. In K. Sawyer (ed.). Cambridge Handbook of the Learning Sciences (pp. 97-118), New York: Cambridge University Press.

Slavin, R. E. (2005). Educational psychology: Theory and practice. London: Pearson Education.

Siemens, G. (2002). Instructional design in elearning. Elearnspace, September 30. Retrieved from: http://www.elearnspace.org/Articles/InstructionalDesign.htm.

Sursock, A. (2015). Trends 2015: Learning and Teaching in European Universities. Brusselles: European University Association. Retrieved from: http://www.eua.be/Libraries/Publications_home page_list/EUA_Trends_2015_web.sflb.ashx.

Wagner, T. (2008). The global achievement gap: Why even our best schools don't teach the new survival skills our children need - and what we can do about it. New York, NY: Basic Books.

Walser, N. (2008). Teaching 21st century skills. Harvard Education Letter, 24(5), 1-3. Retreieved from: https://www.siprep.org/uploaded/ProfessionalDevelopment/Readings/21stCenturySkills.pdf.

Wenglinsky, H. (2005). Technology and achievement: The bottom line. Educational Leadership, 63(4), 29-32.

Vieluf, S., Kaplan, D., Kliemme, E. \& Bayer, S. (2012). Teaching practices and pedagogical innovation: evidence from TALIS. OECD Publishing. Retrieved from: http://dx.doi.org./10.1787/9789264123540en.

Virkus, S. (2008). LIS education in Europe: Challenges and opportunities. In V. Neugebauer (Ed.), Informationskonzepte für die Zukunft: ODOK '07 (pp. 191-204). Retrieved from: http://eprints.rclis.org/ 14978/1/odok07_virkus.pdf.

Virkus, S. (2015). Change and Innovation in European Library and Information Science Education. BiD: 
textos universitaris de biblioteconomia i documentació, 35. Retrieved from: http://bid.ub.edu/en/ 35/virkus.htm.

Winslow, C. (2010). Comparing theoretical frameworks in Didactics of Mathematics: the G-O-A-model. Proceedings of CERME 6, January 28th-February 1st 2009, Lyon France (pp. 1675-1684). Retrieved from: www.inrp.fr/editions/cerme6.

Zhang, J., Scardamalia, M., Lamon, M., Messina, R. \& Reeve, R. (2007). Socio-cognitive dynamics of knowledge building in the work of 9- and 10-year-olds. Educational Technology Research and Development, 55(2), 117-145.

\section{Reccommended websites}

Bologna process and the European Higher Education Area.

https://ec.europa.eu/education/policies/higher-education/bologna-process-and-

european-higher-education-area_en

Tempus programme

https://eacea.ec.europa.eu/sites/2007-2013/tempus-programme_en

Erasmus programme

https://ec.europa.eu/programmes/erasmus-plus/node_en

Leonardo da Vinci programme

https://eacea.ec.europa.eu/sites/2007-2013/llp/leonardo-da-vinci-programme_en

editors

Tatjana Aparac-Jelušić

Serap Kurbanoglu 